\title{
High diversity of anatomical and hydraulic strategies of dominant Amazonian savanna woody species
}

\author{
Priscila F. Simioni \\ UENF: Universidade Estadual do Norte Fluminense Darcy Ribeiro \\ Thaise Emilio \\ UNICAMP: Universidade Estadual de Campinas \\ André L. Giles \\ UNICAMP: Universidade Estadual de Campinas \\ Gustavo Viana de Freitas \\ UENF: Universidade Estadual do Norte Fluminense Darcy Ribeiro \\ Rafael Silva Oliveira \\ UNICAMP: Universidade Estadual de Campinas \\ Lara Setime \\ UENF: Universidade Estadual do Norte Fluminense Darcy Ribeiro \\ Angela Pierre Vitoria \\ UENF: Universidade Estadual do Norte Fluminense Darcy Ribeiro \\ Saulo Pireda \\ UENF: Universidade Estadual do Norte Fluminense Darcy Ribeiro \\ Ivone Vieira da Silva \\ UNEMAT: Universidade do Estado de Mato Grosso \\ Maura Da Cunha ( $\nabla$ maurauenf@gmail.com) \\ Universidade Estadual do Norte Fluminense Darcy Ribeiro
}

\section{Research Article}

Keywords: Cerrado, leaf anatomy, xylem anatomy, water use efficiency, embolism resistance, pit membrane thickness

Posted Date: February 4th, 2022

DOl: https://doi.org/10.21203/rs.3.rs-1247011/v1

License: @) (1) This work is licensed under a Creative Commons Attribution 4.0 International License. Read Full License 


\section{Abstract}

Amazonian savannas are isolated patches of open habitats found within an extensive matrix of tropical rain forest. The climate of Amazonia is transitioning to a state that favors savannas over forests. Still, the hydraulic functioning of savanna species in Amazonian vegetation remains unknown and unexplored. We measured 22 leaf, wood, and hydraulic traits, including embolism resistance (as $\mathrm{P}_{50}$ ) and isotope-based water use efficiency (WUE), for the seven dominant woody species ( $75 \%$ of biomass) of Amazonian savanna. We found wide variation in resistance to embolism ( $-1.66 \pm 0.06 \mathrm{MPa}$ and $-5.07 \pm 0.46 \mathrm{MPa}$ ) with species investing in at least three different hydraulic strategies based on anatomical adjustment: (1) Species with high $\mathrm{G}_{\mathrm{max}}$ and low water use efficiency where leaf succulence may delay embolism onset; (2) Species that have low embolism resistance and high water use efficiency by reinforcing the walls of longer vessel elements to prevent implosion; (3) Species with high $G_{\text {max }}$ and low water use efficiency where short vessel elements and thick intervascular pit membranes may minimize the embolism spread across the plant. Our results suggest no unique dominant functional strategy among Amazonian savanna species illustrating the alternative ways to survive in a hot and seasonally dry environment.

\section{Introduction}

The Amazon Forest is the most diverse tropical forest on the planet and stands out as the main source of Neotropical biodiversity (Antonelli et al., 2018). Although the Amazon is well-known for its forests, a significant part of it is covered by natural grasslands and savanna-like vegetations, grouped under the broader term 'Amazonian savanna' (Pires and Prance, 1985). Amazonian savannas are isolated patches of open habitats found within the extensive matrix of Amazonian tropical forests, and possess floras distinct from that of the surrounding forest (Viana et al., 2016). Global vegetation models predict high vulnerability for Amazonian forests to drought (Huntingford et al., 2008) and even the transition to more open vegetation states (Cox et al., 2004). With deforestation and global warming causing increases in the duration of the dry season, the climate is changing to a state that favors savannas over forests (Nobre and Borma, 2009; Devecchi et al., 2020). However, the most likely scenario is that these transition processes will occur simultaneously, operating at multiple spatial and temporal scales, and interacting strongly. Thus, the knowledge about water use and drought vulnerability in savanna-like vegetations can be instrumental to understand and predict the fade of both, forests and savannas, in the future.

Several studies have been performed on the drought resistance of plant species of the largest tropical forest in the world based on the assessment of their hydraulic traits (Rowland et al., 2015; Santiago et al., 2018; Barros et al., 2019; Bittencourt et al., 2020; Fontes et al., 2020). Together, those studies have shown that Amazonian species exhibit a wide range of embolism resistance (Rowland et al., 2015; Santiago et al., 2018), with plants growing on impoverish Amazonian soils being more resistant to embolism than plants from other tropical forests (Oliveira et al., 2019). Habitat and climate play an important role in embolism resistance by Amazonian species, with species from flooded and highly seasonal forests being more resistant to embolism than species from non-flooded and less seasonal forests (Barros et al., 2019; Fontes et al., 2020). Importantly, taxonomic identity controls adjustments in the hydraulic structure that underlies both hydrological micro-habitat partitioning (Cosme et al., 2017) and acclimation to increasing drought (Bittencourt et al., 2020). In comparison, the functional anatomy and hydraulic functioning of savanna species in Amazonian vegetation remains unknown and unexplored.

Amazonian savannas differ from other savannas due to their high annual precipitation $(\sim 2,180 \mathrm{~mm})$ and from nearby Amazonian forests due to their marked seasonality in rainfall and extreme nutrient-poor soils (Lloyd et al., 2009; 2015). During periods of climatological water deficit, Amazonian savannas show a relatively higher atmospheric vapor pressure deficit (VPD) and temperature than nearby forests. Under water-restricted conditions, plants typically reduce the opening of their stomata, a strategy that significantly reduces water loss through transpiration, but at the same time limits $\mathrm{CO}_{2}$ diffusion for photosynthesis (Galmés et al., 2013; Xiong et al., 2017). Thus, plants must constantly deal with the trade-off of maximizing $\mathrm{CO}_{2}$ diffusion while minimizing water loss through transpiration (Mcadam and Brodribb, 2012). Evidence from plants growing under seasonal drought conditions, including other savannas, suggests co-variance between vessel attributes and stomatal regulation. For example, previous work relates leaf hydraulics, including turgor loss and leaf conductivity, to wood density in central Brazil savannas (e.g. Bucci et al., 2004). However, it is uncertain how those findings can be extended to Amazonian savanna species as less than $50 \%$ of the species are shared between savanna floristic provinces in the Neotropics (Bridgewater et al., 2004). Also, the marked differences in species dominance among savanna provinces suggests that ecological, and perhaps functional, strategies that are advantageous in one region may not be so successful in the others.

A growing knowledge on how anatomical and physiological attributes coordinate to allow plants to adapt to drought shows general trends in the structure of the plants. Xeromorphic characteristics in secondary xylem include the presence of high frequency of vessels, narrower and shorter vessel elements, vasicentric tracheid, thicker fiber walls, thicker intervascular pits, and well-defined growth layers (Carlquist, 1977, 2018; Chave et al., 2009; Lens et al., 2011; Ziemińska et al., 2013). Fusion of wide vessel elements generally forms long vessels, and narrow vessel elements form short vessels (Tyree and Zimmermann, 2002; Nijsse, 2004; Jacobsen et al., 2012). Long vessels transport water more efficiently than short vessels because intervessel transport (ie transport through intervessel pits) largely contributes to resistance to water flow (Comstock and Sperry, 2000; Van leperen et al., 2000; Nijsse et al., 2001). On the other hand, short vessels are safer in case of drought, or mechanical damage, because embolisms generally cannot spread beyond the vessel in which they occur (Comstock and Sperry, 2000; Tyree and Zimmermann, 2002).

It is expected that higher frequency of short vessel elements offer greater resistance to water and air flow as a larger number of end walls must be trespassed (Hacke et al., 2006; Loepfe et al., 2007). Lateral flow mediated by the ultrastructural characteristics of the intervascular pits, especially those related to the pit membrane, can also play an important role in preventing the propagation of air bubbles along the vessel network (Choat et al., 2008; Lens et al., 2011; Li et al., 2016). This process could explain the direct functional link between membrane thickness and resistance to embolism (Jansen et al., 2009; Li et al., 2016; Dória et al., 2018; Trueba et al., 2019). Together, those mechanisms show the potential for coordination of anatomical and 
hydraulic traits, but in which conditions this coordination happen is still unknown. Specifically, we need to better understand how vessel element size and vessel diameter and density are related to the efficiency and safety of water conductivity (Zanne et al., 2010; Lens et al., 2011; Hacke, 2015; Gleason et al., 2016; Li et al., 2016) and what is the role of vessel wall thickness and the membrane of the intervascular pit in the resistance to xylem embolism (Hacke et al., 2001; Jacobsen et al., 2005).

At leaf level, observed patterns on the relationship between anatomical (e.g. cuticle thickness, leaf succulence) and hydraulic (e.g. stomatal conductance, water use efficiency) traits also suggests coordination. Different lines of evidence suggest that minimal transpiration water loss arises from leaks in two main locations: cuticle and stomata (Richardson et al., 2007; Bueno et al., 2019). The maximum stomata conductance is driven by a combination between stomata size and density (de Boer et al., 2016). The plant cuticle covers the outer cell walls of the leaf epidermis, serving to reduce water loss as well as protect against pathogens and UV damage (Schuster et al., 2017). Water restriction and high irradiance reducing isotopic discrimination and increasing the amount of ${ }^{13} \mathrm{C}$ incorporated in the plant's leaf tissue as stomata remain closed longer (Martinelli et al., 1998; Teixeira et al., 2018). From C $\left(\delta^{13} \mathrm{C}\right)$ isotopic ratio we can also estimate the water use efficiency (Martinelli et al., 1998; Vitória et al., 2018), which represents an important integrative trait of functions in the leaf scale. Water use efficiency can be affected by leaf succulency as water stored in the leaf tissues may delay stomata closure by supplying water to sustain hydraulic function (Rosado and De Mattos, 2007; Rosado et al., 2016). This allows the plant to reduce stomatal opening, consequently stomatal conductance (Niinemets, 2001; Vendramini et al., 2002; Rosado and De Mattos, 2007; Grubb et al., 2015; Simioni et al., 2017). Together, this shows how within-organ coordination between leaf structure and function intermediate water loss from plant to atmosphere. Less evidence of coordination between organ is available (but see Méndez-Alonzo et al., 2012). Although stem characteristics, including wood density, $\mathrm{P}_{50}$ and hydraulic conductivity, may not differ significantly between savanna and forest species; leaf properties, such as maximum conductivity and C, can be significantly higher in savanna trees compared to forest (Hao et al., 2008). This suggests that greater leaf hydraulic efficiency may be more critical than stem hydraulics in adapting to seasonality in savanna-like vegetations, but an integrated understanding on how water status control at leaf and stem level are coordinated is currently missing.

In this context, we combined studies of anatomical and hydraulic traits to understand the structure-function relationships of leaf and xylem in plants of Amazonian savannas. We measured 22 leaf, wood, and hydraulic traits of seven dominant woody species, making this the first hydraulic, and the most comprehensive, study to date on anatomical strategies of Amazonian savanna plants. To understand trait-trait relationships among the focal species, we asked:

(i) Do woody species of Amazonian savannas converge or diverge in their hydraulic strategies? Here we hypothesize that trees may adjust their wood and leaf anatomy in different ways to adapt to drought. This will result in the coexistence of several contrasting functional strategies coexisting under the same environmental conditions (Rosado et al., 2013; Dias et al., 2020).

(ii) How are hydraulic and anatomical traits related to each other? We expect some degree of integration between hydraulic and anatomical strategies between different organs, particularly between WUE cuticle thickness and maximum stomata conductance. At branch level, xylem resistance is expected to be higher in species with shorter, narrower and more frequent vessel elements and when pit membranes are thicker.

(iiWhat is the anatomical basis of leaf and branch hydraulic strategies? We hypothesized that different combination of traits at leaf and branch level could be in place to guarantee plant survival with plant anatomy and hydraulics interacting in many ways. We expect leaf succulence to be related to WUE. However, under a high transpiration demand we expect a coordination between leaf and branch hydraulic strategies that favors xylem safety. Together those strategies should be able to reduce the changes of embolism formation and spread that allow species occurrence in Amazonian savannas.

\section{Materials And Methods}

\section{Study area}

The study was conducted in a rocky Amazonian savanna community in the municipality of Nova Canaã do Norte in the state of Mato Grosso, Brazil

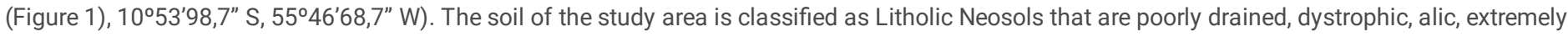
acidic and sandy, and with low nutrient concentrations (Pessoa et al., 2021). The climate of the area is equatorial (Am) hot and humid, according to the Köppen classification, with temperatures varying from $20^{\circ} \mathrm{C}$ to $36^{\circ} \mathrm{C}$ with an annual average above $28^{\circ} \mathrm{C}$ (Alvares et al., 2013). Total annual rainfall can reach 2,180 mm, with two well-defined seasons - a rainy season encompassing November, December, January, February, and March (1,180 mm) and a dry season encompassing June, July, August, and September (108 mm) - with the other months being considered transition periods (Alvares et al., 2013).

\section{Data collection}

The seven most abundant woody plant species in the study area were selected from vegetation representing $75 \%$ of the community plant biomass (Table 1). The following morphological, anatomical, and hydraulic measurements were made for each species: leaf area, leaf succulence, leaf specific mass, stomatal density, adaxial cuticle, maximum theoretical stomatal conductance and carbon isotopic composition (water use efficiency - WUE); theoretical hydraulic conductivity, vessel lumen area, vessel frequency, vessel element length (including the tips, Figure S1), lumen fraction, ray frequency and ray width; fiber lumen, fiber length, wood specific gravity, vessel wall thickness, intervessel pits (often horizontal in tangential sections, Figure S2) and pit membrane thickness (resistance mechanism); and xylem embolism resistance and hydraulic safety margin (embolism vulnerability proxy). Trait sampling and measurements for the species are detailed below. 
Morphological measurements were made of samples from five fully expanded leaves from three individuals of each species. Discs of $0.5 \mathrm{~cm}$ in diameter were removed from the median third of the leaves. The discs were hydrated for $24 \mathrm{~h}$ and dried with paper for subsequent determination of saturated mass ( $\left.\mathrm{M}_{\text {saturated }}\right)$ using a digital balance (AY220, Shimadzu), and thickness with a digital caliper (Stainless, Hardened). The hydrated discs were then placed in an oven set at $55^{\circ} \mathrm{C}$ for $72 \mathrm{~h}$ to obtain dry mass $\left(M_{\text {dry }}\right)$. These parameters were used to calculate leaf succulence $\left(M_{\text {saturated }}-M_{\text {dry }} / A r e a d i s c\right)(K l u g e$ and Ting, 1978) and leaf specific mass ( $M_{\text {dry }} /$ Areadisc) (Kluge and Ting, 1978). Leaf area was determined by digitally scanning the leaves used for the other morphological analyses and then measuring their area using ImageJ digital image processing system.

Leaf cross-sections were made in the middle of the leaf by freehand for measurements of leaf anatomical attributes and to observe the adaxial cuticle. Stomatal density $\left(\mathrm{mm}^{2}\right)$ and stomatal pore length $(\mu \mathrm{m})$ were determined from the analysis of images of epidermis dissociated by the Franklin method (Franklin, 1945). Theoretical maximum stomatal conductance was calculated from the relationship between stomatal pore density and size (de Boer et al., 2016), according to the following equation:

$\mathrm{G}_{\max }=\mathrm{D} \times \mathrm{L}(\mathrm{Eq} 1$.

where $G_{m a x}$ is maximum stomatal conductance $\left(m m \cdot s^{-1}\right), D$ is stomatal density $\left(\mathrm{mm}^{2}\right)$ and $L$ is stomatal length $(\mu m)$.

\section{Scanning electron microscopy}

Two leaves were selected for each species for investigation of stomatal morphology on the abaxial leaf face. Fragments of the median third of the leaf blade were fixed in an aqueous solution of $2.5 \%$ glutaraldehyde, $4 \%$ formaldehyde, and $0.05 \mathrm{M}$ sodium cacodylate buffer at $\mathrm{pH} 7.2$ (Karnovsky, 1965 modified by Da Cunha et al., 2000) and then post-fixed in 1\% osmium tetroxide and $0.05 \mathrm{M}$ sodium cacodylate buffer for $2 \mathrm{~h}$ at room temperature. After fixation, the samples were submitted to acetone dehydration, followed by $\mathrm{CO}_{2}$ critical point drying (CPD 030, Baltec). The samples were then adhered to stubs with carbon tape and covered with a layer of approximately $20 \mathrm{~nm}$ of gold (SCD 050, Baltec, Switzerland). Images were obtained using a ZEISS EVO 40 (Germany) scanning electron microscope at a voltage of $15 \mathrm{kV}$.

\section{Carbon isotopic composition $\left(\delta^{13} \mathrm{C}\right)$}

For determining $\delta^{13} \mathrm{C}$, five leaves were selected from three individuals of each species. The leaves were dried in an oven at $60{ }^{\circ} \mathrm{C}$ for $72 \mathrm{~h}$ and then macerated. After maceration, the five leaves for each individual were homogenized. The homogenized material was subsequently weighed (1.5 mg) with a precision analytical balance. Data were obtained using a Thermo Finnigan Delta V Advantage mass spectrometer coupled to a Flash 2000 (Thermo 26 Fisher Scientific in Bremen, Germany) elemental analyzer at the Laboratório de Ciências Ambientais from Universidade Estadual do Norte Fluminense Darcy Ribeiro. Pee Dee Belemnite (PDB) was used as the standard value for C. The analytical precision was $\pm 0.1 \%$, while the precision of the elemental and isotopic compositions was determined by certified standard (Protein OAS/IsotopeCert 114859; Elemental Microanalysis).

\section{Branch}

Branch samples were sectioned (15-20 $\mu$ m thickness) in transversal and longitudinal tangential planes using a sliding microtome (SM2010 R, LEICA, Germany). The sections were then clarified in sodium hypochlorite $(50 \%)$ and acidulated water $(0.1 \%)$, dehydrated in an ascending ethanol series ( $50 \%$ to $100 \%$ ) (Johansen, 1940), stained with Astra blue and hydro-alcoholic Safranin, and immersed in xylene P.A. Permanent slides were made using Entellan ${ }^{8}$ (Merck) synthetic resin.

We used a maceration method for the measurements of vessel element length (including tips) and fiber length. Maceration of branch material followed Franklin (1945). Small branch fragments were removed from each sample and placed in bottles containing a macerating solution of glacial acetic acid and hydrogen peroxide (1:1). The bottles were then sealed and placed in an oven at $60^{\circ} \mathrm{C}$ for $24 \mathrm{~h}$ or until the complete dissociation of cells. The material was then washed in distilled water, stained with $1 \%$ aqueous Safranin, and mounted on semi-permanent slides with glycerin. Imperforate tracheary elements were not observed in macerations for any of our samples, as it is common among Angiosperm species.

Quantitative analysis was performed using 12 slides per individual. All descriptions, counts and branch cellular measurements followed IAWA Committee standards (1989). Permanent and semi-permanent slides were analyzed using a light-field light microscope (Axioplan, ZEISS, USA), with image capture via a coupled camera (Power shot A640, CANON, USA).

\section{Transmission electron microscopy}

Two branches of each species were selected for analysis of the intervascular pit membrane. Branch fragments were fixed in modified Karnovsky solution (Karnovsky, 1965 modified by Da Cunha et al., 2000). Post-fixed in 1\% osmium tetroxide and $0.05 \mathrm{M}$ sodium cacodylate buffer $2 \mathrm{~h}$ at room temperature, and then dehydrated in an increasing acetone series and infiltrated and embedded with epoxy resin (Epon $\left.{ }^{\circledR}\right)$. Ultrathin sections ( $\left.80 \mathrm{~nm}\right)$ were made using an ultramicrotome (Reichert Ultracuts Leica Instruments) with a diamond knife (Diatome $\left.{ }^{\circledR}\right)$, which were collected in copper grids (300 mesh) and contrasted with $1.0 \%$ alcoholic uranyl acetate, followed by $5.0 \%$ aqueous lead citrate (Reynolds, 1963). Ultrastructure analysis of pit membranes was performed using a JEM 1400 Plus JEOL transmission electron microscope at a voltage of $80 \mathrm{kV}$, with 20 observations per individual. Measurements of anatomical attributes (Table 2) were performed using Image Pro-Plus 4.0 digital image processing system. Pit membrane thickness was measured cuts 
made in the sapwood at three different points, later averaged to represent the sample pit membrane thickness (Figure S4). All measurements for each species were made from three individuals with similar height and two branches between 1.5 and $2 \mathrm{~cm}$ diameter per individual.

Wood specific gravity

Wood specific gravity was calculated by first measuring the fresh volume of wood samples by displacement of a water column (Williamson and Wiemann, 2010). Samples were immersed in a beaker containing water on top of a digital balance and sample volume was converted from the weight of displaced water (e.g., $1 \mathrm{~g}=1 \mathrm{~cm}^{3}$ ). Dry mass was obtained by drying the samples in an oven at $105^{\circ} \mathrm{C}$ for $72 \mathrm{~h}$. Wood specific gravity was then calculated as:

\section{WSG $=\mathrm{Dm} / \mathrm{Dv}(\mathrm{Eq} 2)$}

where WSG = wood specific gravity $\left(\mathrm{g} \cdot \mathrm{cm}^{-3}\right), \mathrm{Dm}=$ dry mass, and Dv = displaced volume.

Theoretical hydraulic conductivity

Theoretical hydraulic conductivity $\left(\mathrm{K}_{\mathrm{th}}\right)$ was calculated for each sampled individual from vessel lumen area using the Hagen-Poiseuille equation:

\section{$\mathrm{K}_{\mathrm{th}}=\pi \mathrm{D} 4 / 128 \eta(\mathrm{Eq} 3)$}

where $\mathrm{K}_{\mathrm{h}}=$ theoretical hydraulic conductivity in $\mathrm{kg} \cdot \mathrm{s}^{-1} \cdot \mathrm{m}^{-1} \cdot \mathrm{MPa}^{-1}, \eta=$ water viscosity at $20^{\circ} \mathrm{C}\left(1.002 \times 10^{-3}\right.$ Pa.s $)$ and $\mathrm{D}=$ hydraulically weighted vessel diameter in $\mathrm{mm}$.

Because cross-sections of vessels are not perfect circles, vessel lumen area was used to calculate equivalent vessel diameter (d) (Scholz et al., 2013) as:

\section{$d=\sqrt{4 A} \cdot \pi(E q 4)$}

where $\mathrm{A}=$ vessel lumen area.

Hydraulically weighted vessel diameter (D) was calculated as:

\section{$D=\left(\Sigma d^{4} / N\right)^{0.25}(E q 5)$}

where $\mathrm{d}=$ equivalent vessel diameter in $\mathrm{mm}$, and $\mathrm{N}=$ number of measured vessels .

Embolism resistance and hydraulic safety $\left(P_{50}\right.$ and HSM)

Branches of 1.5 to $2.0 \mathrm{~m}$ in length were collected at dawn for assessing embolism resistance and hydraulic safety $\left(\mathrm{P}_{50}\right.$ and HSM). Ten to $15 \mathrm{~cm}$ long segments were cut from the base of each branch under water and were allowed to rehydrate for $12 \mathrm{~h}$, keeping them covered and sealed by black plastic bags. Hydraulic measurements were then made on the distal end of each branch to ensure there were none artificially embolized vessels in the measured sample. All samples used for hydraulic measurements were from first or second-order branches that were $30-55 \mathrm{~cm}$ in length and 2-4 cm in diameter and were cut under water with a sharp blade before connecting to the apparatus to ensure that all vessels were open. We measure the water potential of the leaves after 12 hours of hydration, taken to represent the timepoint when transpiration is at its minimum and the water potential of the plant is closest to equilibrium with that of the soil. We also determined midday water potential ( $\left.\Psi_{\mathrm{md}}\right)$, to capture the minimum $\Psi$ of the plant in the dry season (Figure $\left.S 5\right)$, leaf water potentials were measured using a pressure chamber (Model 1505, PMS). This measure is affected by any cuticular or stomatal transpiration and, thus, broadly captures the integrated effects of plant traits and the environment water demand on the minimum water potential a plant reaches in natural conditions.

$P_{50}$ was used as an embolism resistance index, which is water potential corresponding to a $50 \%$ loss of xylem conductivity. $P_{50}$ was used to calculate the hydraulic safety margin (HSM; i.e., the difference between $\mathrm{P}_{50}$ and $\Psi_{\mathrm{md}}$ ), which is a good predictor of drought resistance (Barros et al., 2019). Xylem embolism resistance of each branch was measured using the pneumatic method in the manual measurements set-up (Pereira et al., 2016; Zhang et al., 2018). With this method, loss of hydraulic conductance is estimated from the increase in air volume inside the wood caused by the formation of an embolism, as the branch dehydrates (for details of the methods see Bittencourt et al., 2018). Branches were dehydrated using the bench dehydration method (Sperry et al., 1988). The branches were bagged for an hour to balance the water potential of the xylem with that of the leaves before each air removal measurement. The volume of air reservoir was as adjusted when a rapid drop in air discharge or values close to atmospheric pressure were detected to preserve the accuracy of the method. The reservoir volume varied between 1.305 to 2.610 depending on the species and/or individuals the volume. Water potential of one or two leaves was measured immediately after air removal. Embolism resistance is then given by increasing air removal (PAD = the percentage of air removed) with each tree xylem water potential. To calculate $P_{50}$, we gathered data for the repetitions of two branches of the same tree and adjusted a sigmoid curve to the data where $\mathrm{P}_{50}$ and slope are the adjusted parameters (Pammenter and Willigen, 1998).

$P A D=100 /\left(1+\exp \left(a\left(\Psi-P_{50}\right) \cdot(\right.\right.$ Eq 5$)$ 
Characterization of $\mathrm{P}_{50}$ was done for the seven dominant species of the community. The pneumatic method was applied to the branches to construct vulnerability curves for the xylem. We were not able to produce reliable vulnerability curves to Macareia radula and Alchornea discolor using the pneumatic method most likely due to an undetected leakage during the measurements in the field. After inspecting the curves, we observed large amount of variation in the initial and final measurements, and consequently, poor fit of the curves. Both species have very tick bark and fast shrinkage requiring fitting adjustments during the measurements. We believe that this may have caused air leakage and for this reason we were not confident to use the data collected for both species for the analysis. The $\mathrm{P}_{50}$ and HSM are presented for the remaining five dominant species: N. guianensis, S. versicolor, $P$. cachimboensis, K. rubriflora and M. guianensis (Figure S6).

\section{Statistical analysis}

To determine morphological, anatomical, and ecophysiological variables related to transpiration, water transport, and xylem vulnerability, we made pairwise tests of the relationships between attributes due to the high degree of correlation. Only attributes directly related to our hypotheses were considered for pairwise relationships.

The Shapiro-Wilk normality test was used to test the assumptions of regression and choose methods for data analysis. A correlation matrix was constructed to observe associations among the variables of this study. Correlations were performed using the non-parametric statistics to calculate Spearman's Coefficient (rho) as data and variables did not follow a normal distribution even after transformation. A graph was constructed from the correlation matrix to show the observed relationships within an intuitive model of expected relationships. The model was proposed based on leaf and wood anatomical and hydraulic attributes to explain correlated mechanisms between leaf transpiration, water transport mechanism, and resistance to embolism.

Pairwise regression models were adjusted for water use efficiency, xylem embolism vulnerability, hydraulic safety margin, and anatomical variables to evaluate the anatomical basis for observed variation in ecophysiological attributes. Adjusted coefficients of determination $\left(R^{2}\right), 95 \%$ confidence intervals and $\mathrm{p}$-values are reported. The adjusted regression models were corrected through a multiple comparison test (Bonferroni test). The data were transformed when necessary to meet the assumptions of regression (linearity, homoscedasticity, normality, and low leverage).

The data were scaled to standard deviation units to perform a principal component analysis (PCA), to ordinate possible plant strategies and select the variables that contribute most to species clustering. Descriptive statistical analysis, correlation matrix, regression models, and principal component analysis were performed using $\mathrm{R}^{\odot}$ software (R Core Team, 2019).

\section{Results}

\section{Anatomical and hydraulic diversity}

The dominant woody species in the studied Amazonian savanna have anatomical (Figure 2) and hydraulic diversity of leaf and wood (Table 2). Variation by a factor of two to three was observed among the seven species for most attributes, including leaf area, vessel frequency, lumen area, lumen fraction, intervascular wall thickness, fiber length, $P_{50}$, stomatal density, and $G_{\max }$. This variation was even greater, five times or more, for the attributes of succulence and HSM. Exceptions to this pattern were the attributes of wood density, water use efficiency $\left(\delta^{13} \mathrm{C}\right)$, and pit membrane thickness, which varied $10-30 \%$ among species. It is worth mentioning that the relative ordering of species varied according to attributes (Figure S7), with no species having a consistent pattern of covariation for several attributes simultaneously.

\section{Correlation between attributes}

Stomatal conductance is negatively correlated with water use efficiency of leaves, which in turn positively correlated with vessel element length ( $r=0.90$ $p \leq 0.01)$ and negatively correlated with $P_{50}(r=-0.64 p \leq 0.01)$. Vessel frequency is negatively correlated with vessel element size $(r=-0.62 p \leq 0.01)$ and lumen area $(r=-0.65 p=0.002)$. Vessels with smaller lumen area correlate negatively with higher lumen fraction per area $(r=-0.59 p=0.004)$, the latter of which has a negative correlation with $P_{50}(r=-0.76 p \leq 0.01)$. The thickness of the intervascular pit membrane is negatively correlated with $P_{50}(r=-0.61$ $\mathrm{p}=0.02)$ and positively with safety margin $(\mathrm{r}=0.61 \mathrm{p}=0.02)$.

Pairwise relationships between anatomical and hydraulic attributes

Significant relationships were found between anatomical and hydraulic attributes of leaf and wood (Figure 4$)$. Water use efficiency $\left(\delta^{13} \mathrm{C}\right)$ decreased with $G_{\max }\left(r^{2}=0.50 ; p \leq 0.01\right)$ (Fig. 4A) and with lumen fraction $\left(r^{2}=0.56 ; p=0.002\right)$ (Fig. 4B). Among the wood anatomical variables evaluated here, only vessel element length and thickness of the membrane of the intervascular pit were significantly related to xylem vulnerability (Figure 4$)$. The attribute $P_{50}$ increased with vessel element length $\left(r^{2}=0.77 ; p=0.04\right)$ and decreased with the thickness of the membrane of the intervascular pit $\left(r^{2}=0.43 ; p \leq 0.01\right)($ Fig. $4 C ; 4 D)$. The attribute HSM decreased with the length of the vessel element $\left(r^{2}=0.69 ; p \leq 0.01\right)$ and increased with the thickness of the pit membrane $\left(r^{2}=\right.$ $0.42 ; \mathrm{p} \leq 0.01$ ) (Fig. 4E, 4F).

\section{Anatomical and hydraulic strategies}

The principal component analysis (PCA) explained $73.92 \%$ of the total variation with the first two axes (Figure 5). The first axis explained $54.12 \%$ of the total variation and presented species with high water use efficiency, long vessels and fibers, and vessels with thicker walls, such as $N$. guianensis and $A$. 
discolor. The second axis explained $19.8 \%$ of the total variation and represented species with higher wood density, a greater lumen fraction, greater thickness of the membrane of the intervascular pit, higher theoretical maximum stomatal conductance $\left(G_{\text {max }}\right)$ and greater leaf succulence and specific leaf mass, such as S. versicolor, M. radula, P. cachimboensis, K. rubriflora, and M. guianensis.

\section{Discussion}

This study provides the first data about hydraulic structure and functioning of woody species from Amazonian savannas. Our findings showed wide variation in resistance to embolism and structural anatomy, suggesting no unique dominant functional strategy among Amazonian savanna species. The species diverge by investing in three different functional strategies for drought tolerance: (1) Species with high $G_{\text {max }}$ and low water use efficiency where leaf succulence may delay embolism onset and high wood specific gravity enables more negative pressures on the xylem (Kielmeyera rubriflora, Simarouba versicolor and Macairea radula); (2) Species that have low embolism resistance and high water use efficiency by reinforcing the walls of longer vessel elements to prevent implosion (Norantea guianensis and Alchornea discolor); (3) Species with high $\mathrm{G}_{\mathrm{max}}$ and low water use efficiency where short vessel elements and thick intervascular pit membranes may minimize the embolism spread across the plant (Maprounea guianensis and Parkia cachimboensis).

\section{Local divergence in drought-induced embolism resistance}

Amazonian savanna species studied here diverged widely regarding their vulnerability to embolism. We observed extremely vulnerable species, such as $N$. guianensis $\left(\mathrm{P}_{50}=-1.66 \mathrm{MPa}\right)$, coexisting with drought-resistant species, such as $P$. cachimboensis $(-5.07 \mathrm{MPa})$, M. guianensis (-4.56 MPa), S. versicolor $(-4.40 \mathrm{MPa})$, and K. rubriflora (-3.87 MPa). This variation was observed when comparing safety margins among species, which also varied widely (c.f. Table 2). Although, at global scale is observed a very clear pattern of less negative $P_{50}$ in wetter habitats and more negative $P_{50}$ in drier habitats (Choat et al., 2012; O'Brien et al., 2017) similar amounts of variation can be also observed under the same climate among coexisting species as shown here. Variation in $\mathrm{P}_{50}$ within each location observed in the global studies suggests that adaptations other than drought-induced embolism resistance may be in place to allow the colonization of drier habitats for different species. Our results reinforce this by showing that different combination of leaf and xylem hydraulic strategies explain some of the variation in drought-induced embolism resistance observed locally.

\section{Integration of structure and hydraulic functioning of plants}

Integrative anatomical and physiological studies are essential for understanding the diversity of drought resistance mechanisms of coexisting species in seasonal environments. Here we show that species that are less efficient in water use (e.g. K. rubriflora, M. radula, S. versicolor, $P$. cachimboensis, and $M$. guianensis) show lower degree of stomatal control (high $\mathrm{G}_{\mathrm{max}}$ ) supporting xylem functioning with leaf succulency and/or safer wood anatomical structures. Alternatively, species that are more efficient in water use (e.g. N. guianensis and A. discolor), have greater control of transpiration, thus incorporating and fixing more ${ }^{13} \mathrm{C}$ in leaf tissues. With greater stomatal control, a lower fraction of lumen may be required to sustain the transpiration demand of these species. Thus, this control over stomatal opening may be a strategy to avoid cavitation in the xylem, as species presenting this strategy tend to have long vessel elements of greater diameter.

Vessel length and diameter directly determines water transport efficiency, and the hypothesis that there is a trade-off between safety and efficiency of the xylem has often been raised (Gleason et al., 2016). This hypothesis proposes that the xylem anatomy drives safety and efficiency but that the vessel characteristics cannot promote safety and efficiency at the same time. Our findings support this view as most resistant species do have shorter vessel elements with smaller diameters. In this case, transport safety is ensured by increasing the thickness of vessel walls to provide sufficient mechanical strength avoiding potential implosion under tension, especially if a vessel filled with water touches an embolized vessel (Hacke et al., 2001; Sperry et al., 2005). The secondary xylem of this group of species is structured by a higher frequency of short vessel elements with thick pit membranes and smaller diameters, which safely increases the fraction of lumen for water transport. Flow resistance is augmented as element vessel size decreases as water need to flow through a larger number of end walls with impacts to the plant's hydraulic conductivity (Loepfe et al., 2007). Here we show that plants with short vessel elements and higher frequency and clustering of vessels also show high lumen fraction. This may be associated with a strategy to compensate for the loss of hydraulic conductivity, since this hydraulic architecture increases the options for transport routes through the vessels.

Some controversy on the functional role of vessel grouping to xylem safety is present in the literature. Tyree \& Zimmermann (2002) and Lens et al. (2011) showed that the grouping of vessels can improve embolism resistance. On the other hand, Loepfe, Martinez-Vilalta, Piñol \& Mencuccini (2007) and Martínez-Vilalta et al. (2012) suggested the opposite, that is, high clustering of vessels is related to low security by increasing the probability of embolism propagation. Here, we observed greater clustering of vessels associated with embolism resistance confirming the importance of grouping to xylem safety. Again, in those species protection against embolism spread may be guaranteed by thicker intervascular pit membranes, which are related to decreased air propagation from embolized vessels to functional vessels (Lens et al., 2011; Dória et al., 2018). Our results also confirm the functional importance of the intervascular pit membrane drought-induced embolism resistance in Amazonian savanna species. Here we show that drought-induced embolism and HSM were significantly related to vessel element length and thickness of the membrane of the intervascular pit and that short vessel elements with thick membranes guaranteeing safe water transport for the studied species. Together, our results suggest that investigating the the role of anatomical structures to hydraulic function in a more integrative way can reconcile the different expectations about the role of individual anatomical features on hydraulic functioning. 
Finally, structural adjustments to allow safe or efficient water transport may not be restricted to xylem but also be related to parenchymatic tissues. A study of 800 species of trees in China found axial parenchyma to be related to theoretical hydraulic conductivity, and radial parenchyma to be related mechanical support (Zheng and Martínez-Cabrera, 2013), which may explain the increase in radial parenchyma in species with greater lumen area. Chen et al. (2020) obtained similar results for 10 species in an arid limestone habitat in China. Their results showed that resistance to embolism was positively correlated with xylem mechanical resistance indicators and negatively related to the fraction of axial parenchyma. These authors suggested that tree species with more axial parenchyma may not need high resistance to embolism to adapt to drought. The present study did not analyze xylem at the parenchymatic tissue level, but variation in the amount of axial and radial parenchyma among species was observed in the anatomical images suggests that this may be one of the mechanisms that allow vulnerable species (e.g. Norantea guianensis) to persist on Amazonian savanna's environmental conditions. Future studies relating anatomical features, tissue capacitance and xylem function may shed some light on this interesting strategy.

\section{No single anatomical or hydraulic strategies to colonize Amazonian savannas}

The main novelty of the present study is that it shows no convergence of strategies for species to be dominant in Amazonian savannas, but rather there is a set of anatomical and hydraulic attributes that vary together, reflecting the specific responses of each species to drought. Vessel element length and pit membrane thickness explained resistance to embolism while leaf succulence allow for less conservative water use strategies. Although the species of Amazonian savannas present divergent strategies, this coordination between leaf and wood is observed for the balance of water supply.

Our results demonstrate a strong degree of coordination between water transport and stomatal regulation. The observed relationships among the characteristics are probably a result of trade-offs favoring the functional coordination between leaves and wood. Decreased stomatal conductance is accompanied by a decline in leaf photosynthesis and increased water use efficiency, with greater stomatal control in the dry season (Janssen et al., 2020). Declines in hydraulic conductance and stomatal conductance with decreasing water potential of the xylem are similar (Brodribb et al., 2003), suggesting that hydraulic vulnerability of xylem and stomatal sensitivity are strongly coordinated.(Meinzer et al., 2008; Fontes et al., 2018; Maréchaux et al., 2018; Garcia et al., 2021) The limited space within the xylem and the resources available for its construction should lead to a three-way exchange among the main functions of the branch: mechanical support, conduction, and storage of water and photoassimilates (Pratt et al., 2007; Zanne et al., 2010). Allometry appears to be regulated at the scale of the entire plant so that water demand and supply are compatible (Brodribb, 2009). Therefore, understanding the coupling between stomatal conductance and xylem hydraulic architecture expands our mechanistic knowledge about plants in an integrated way. Here we contribute to this understanding by showing that these mechanisms can be manifested in different strategies among coexisting plants, converging on safe structures, although in different organs.

\section{Conclusion}

This study provides new insights into the different strategies that plants can exhibit in an integrated manner and represents the first work to estimate xylem embolism resistance in Amazonian savanna species. Our results demonstrate that species that inhabit a restrictive environment, such as Amazonian savannas, can exhibit different strategies of drought tolerance/avoidance resulting in the similar outcome of maintaining a favorable water balance that allow their persistence and co-occurrence. Distinct strategies to deal with drought permitted wide divergence regarding embolism vulnerability. The strategies that selected high xylem embolism resistance are explained by vessel element size and pit membrane thickness. However, the role of strategies related to drought avoidance should not be neglected in this ecosystem. Future climate predictions should aim to incorporate this range of strategies and could be used to test whether future climates will favor some strategies or still allow for a range of them to persist. Further studies and refinement of model exercises are likely to improve our predictions on changing the species and trait composition of Amazonian savannas and also its impact of large scale ecosystem functioning.

\section{Declarations}

\section{Acknowledgments}

This study was financed in part by the Coordenação de Aperfeiçoamento de Pessoal de Nível Superior - Brasil (CAPES) - Finance Code 001; Conselho Nacional de Desenvolvimento Científico e Tecnológico (CNPq); and Fundação de Amparo à Pesquisa do Rio de Janeiro (FAPERJ). RSO received a productivity CNPq scholarship. ALG thank the UNICAMP postgraduate program in Ecology and the Brazilian Higher Education Co-ordination Agency (CAPES). We thank Centro Multiusuário CME-LBCT for providing infrastructure and B. F. Ribeiro for technical work in laboratory of LBCT/CBB/ UENF. This study is a part of the PhD thesis of P.S. carried out at UERJ.

\section{Conflicts of interest}

The authors declare there is no conflict of interest.

\section{Data Availability}

All data supporting the findings of this study are available within the paper and within its supplementary materials published online.

\section{Authors' contributions}


PS collected and compiled the data alongside ALG, GVF, SP and LS. TE designed the study with MDC. PS, ALG and GVU performed the statistical analysis and PS, TE and MDC wrote the paper, with all other authors making substantially contributions to revisions.

Ethics approval (Not applicable)

Consent to participate (Not applicable)

Consent for publication (Not applicable)

Code availability (Not applicable)

\section{References}

1. Alvares CA, Stape JL, Sentelhas PC, De Moraes Gonçalves JL, Sparovek G. 2013. Köppen's climate classification map for Brazil. Meteorologische Zeitschrift 22, 711-728.

2. Antonelli A, Zizka A, Carvalho FA, Scham R, Bacon CD, Silvestro D, Condamine FL. 2018. Amazonia is the primary source of Neotropical biodiversity. Proceedings of the National Academy of Sciences of the United States of America 115, 6034-6039.

3. Barros F de V., Bittencourt PRL, Brum M, et al. 2019. Hydraulic traits explain differential responses of Amazonian forests to the 2015 El Niño-induced drought. New Phytologist 223, 1253-1266.

4. Bittencourt P, Pereira L, Oliveira R. 2018. Pneumatic Method to Measure Plant Xylem Embolism. Bio-Protocol 8, 1-14.

5. Bittencourt PRL, Oliveira RS, Costa ACL, Giles AL, Coughlin I, Costa PB, Bartholomew DC, Ferreira LV, Vasconcelos SS, Barros FV, Junior JAS, Oliveira AAR, Mencuccini M, Meir P, Rowland L. 2020 Amazonia trees have limited capacity to acclimate plant hydraulic properties in response to long-term drought. Global Change Biology 26, 3569- 3584.

6. de Boer HJ, Price CA, Wagner-Cremer F, Dekker SC, Franks PJ, Veneklaas EJ. 2016. Optimal allocation of leaf epidermal area for gas exchange. New Phytologist 210, 1219-1228.

7. Bridgewater S, Ratter JA, Ribeiro JF. 2004. Biogeographic patterns, b-diversity and dominance in the cerrado biome of Brazil. Biodiversity and Conservation 13, 2295-2318.

8. Brodribb TJ. 2009. Xylem hydraulic physiology: The functional backbone of terrestrial plant productivity. Plant Science 177, $245-251$.

9. Brodribb TJ, Holbrook NM, Edwards EJ, Gutiérrez M V. 2003. Relations between stomatal closure, leaf turgor and xylem vulnerability in eight tropical dry forest trees. Plant, Cell and Environment 26, 443-450.

10. Bucci SJ, Goldstein G, Meinzer FC, Scholz FG, Franco AC, Bustamante M. 2004. Functional convergence in hydraulic architecture and water relations of tropical savanna trees: From leaf to whole plant. Tree Physiology 24, 891-899.

11. Bueno A, Alfarhan A, Arand K, Burghardt M, Deininger AC, Hedrich R, Leide J, Seufert P, Staiger S, Riederer M. 2019. Effects of temperature on the cuticular transpiration barrier of two desert plants with water-spender and water-saver strategies. Journal of Experimental Botany 70, 1627-1638.

12. Carlquist S. 1977. Ecological Factors in Wood Evolution: A Floristic Approach. American Journal of Botany 64, 887.

13. Carlquist S. 2018. Living Cells in Wood 3. Overview; Functional Anatomy of the Parenchyma Network. Botanical Review 84, $242-294$.

14. Chave J, Coomes D, Jansen S, Lewis SL, Swenson NG, Zanne AE. 2009. Towards a worldwide wood economics spectrum. Ecology Letters 12, 351366.

15. Chen Z, Zhu S, Zhang Y, Luan J, Li S, Sun P, Wan X, Liu S. 2020. Trade-off between storage capacity and embolism resistance in the xylem of temperate broadleaf tree species. Tree physiology 40, 1029-1042.

16. Choat B, Cobb AR, Jansen S. 2008. Structure and function of bordered pits: New discoveries and impacts on whole-plant hydraulic function. New Phytologist 177, 608-626.

17. Choat B, Jansen S, Brodribb TJ, et al. 2012. Global convergence in the vulnerability of forests to drought. Nature 491, $752-755$.

18. Comstock JP, Sperry JS. 2000. Theoretical considerations of optimal conduit length for water transport in vascular plants. New Phytologist 148, 195218.

19. Cosme LHM, Schietti J, Costa FRC, Oliveira RS. 2017. The importance of hydraulic architecture to the distribution patterns of trees in a central Amazonian forest. New Phytologist 215, 113-125.

20. Cox PM, Betts RA, Collins M, Harris PP, Huntingford C, Jones CD. 2004. Amazonian forest dieback under climate-carbon cycle projections for the 21st century. Theoretical and Applied Climatology 78, 137-156.

21. Da Cunha M, Gomes VM, Xavier Filho J, Attias M, Souza W, Miguens FC. 2000.

22. Laticifer system of Chamaesyce thymifolia: a closed host environment for trypanosomatids. Biocell 24, 123-132

23. Devecchi MF, Lovo J, Moro MF, Andrino CO, Barbosa-Silva RG, Viana PL, Giulietti A, Antar G, Watanabe MTC, Zappi DC. 2020. Corrigendum to: Beyond forests in the Amazon: biogeography and floristic relationships of the Amazonian savannas. Botanical Journal of the Linnean Society, 1-26.

24. Dias ATC, Rosado BHP, De Bello F, Pistón N, De Mattos EA. 2020. Alternative plant designs: Consequences for community assembly and ecosystem functioning. Annals of Botany 125, 391-398.

Page $9 / 18$ 
25. Dória LC, Podadera DS, del Arco M, Chauvin T, Smets E, Delzon S, Lens F. 2018. Insular woody daisies (Argyranthemum, Asteraceae) are more resistant to drought-induced hydraulic failure than their herbaceous relatives. Functional Ecology 32, 1467-1478.

26. Fontes CG, Dawson TE, Jardine K, McDowell N, Gimenez BO, Anderegg L, Negrón-Juárez R, Higuchi N, Fine PVA, Araújo AC, Chambers JQ. 2018. Dry and hot: The hydraulic consequences of a climate change-type drought for Amazonian trees. Philosophical Transactions of the Royal Society B: Biological Sciences 373 .

27. Fontes CG, Fine PVA, Wittmann F, Bittencourt PRL, Piedade MTF, Higuchi N, Chambers JQ, Dawson TE. 2020. Convergent evolution of tree hydraulic traits in Amazonian habitats: implications for community assemblage and vulnerability to drought. New Phytologist 228, $106-120$.

28. Franklin GL. 1945. Preparation of thin sections of synthetic resins and wood-resin Writing - review \& editing, Supervision, Project administration, composites, and a new macerating method for wood. Nature 155, 51.

29. Galmés J, Ochogavía JM, Gago J, Roldán EJ, Cifre J, Conesa MA. 2013. Leaf responses to drought stress in Mediterranean accessions of Solanum lycopersicum: Anatomical adaptations in relation to gas exchange parameters. Plant, Cell and Environment 36, 920-935.

30. Garcia MN, Ferreira MJ, Ivanov V, dos Santos VAHF, Ceron JV, Guedes AV, Saleska SR, Oliveira RS. 2021. Importance of hydraulic strategy trade-offs in structuring response of canopy trees to extreme drought in central Amazon. Oecologia 197, 13-24.

31. Gleason SM, Westoby M, Jansen S, et al. 2016. Weak tradeoff between xylem safety and xylem-specific hydraulic efficiency across the world's woody plant species. New Phytologist 209, 123-136.

32. Grubb PJ, Marañón T, Pugnaire FI, Sack L. 2015. Relationships between specific leaf area and leaf composition in succulent and non-succulent species of contrasting semi-desert communities in south-eastern Spain. Journal of Arid Environments 118, 69-83.

33. Hacke U. 2015. Functional and ecological Xylem anatomy. Functional and Ecological Xylem Anatomy 4, 1-281.

34. Hacke UG, Sperry JS, Pockman WT, Davis SD, McCulloh KA. 2001. Trends in wood density and structure are linked to prevention of xylem implosion by negative pressure. Oecologia 126, 457-461.

35. Hacke UG, Sperry JS, Wheeler JK, Castro L. 2006. Scaling of angiosperm xylem structure with safety and efficiency. Tree Physiology $26,689-701$.

36. Hao GY, Hoffmann WA, Scholz FG, Bucci SJ, Meinzer FC, Franco AC, Cao KF, Goldstein G. 2008. Stem and leaf hydraulics of congeneric tree species from adjacent tropical savanna and forest ecosystems. Oecologia 155, 405-415.

37. Huntingford C, Fisher RA, Mercado L, et al. 2008. Towards quantifying uncertainty in predictions of Amazon 'dieback'. Philosophical Transactions of the Royal Society B: Biological Sciences 363, 1857-1864.

38. Van leperen W, Van Meeteren U, Van Gelder H. 2000. Fluid ionic composition influences hydraulic conductance of xylem conduits. Journal of Experimental Botany 51, 769-776.

39. Jacobsen AL, Brandon Pratt R, Tobin MF, Hacke UG, Ewers FW. 2012. A global analysis of xylem vessel length in woody plants. American Journal of Botany 99, 1583-1591.

40. Jacobsen AL, Ewers FW, Pratt RB, Paddock WA, Davis SD. 2005. Do xylem fibers affect vessel cavitation resistance? Plant Physiology 139, 546-556.

41. Johansen DA. 1940. Plant microtechnique. McGraw-Hill Book Co. Inc., New York 523 p.

42. Jansen S, Choat B, Pletsers A. 2009. Morphological variation of intervessel pit membranes and implications to xylem function in angiosperms. American Journal of Botany 96, 409-419.

43. Janssen T, Fleischer K, Luyssaert S, Naudts K, Dolman H. 2020. Drought resistance increases from the individual to the ecosystem level in highly diverse Neotropical rainforest: A meta-analysis of leaf, tree and ecosystem responses to drought. Biogeosciences 17, $2621-2645$.

44. Karnovsky MJ. 1965. A formaldehyde-glutaraldehyde fixative of high osmolality for use in electron-microscopy. Journal of Cell Biology 27 , 137A138A.

45. Kluge M, Ting IP. Crassulacean Acid Metabolism: Analysis of an Ecological gimes. 1978. Botanical Journal of the Linnean Society 136, $231-238$.

46. Lens F, Sperry JS, Christman MA, Choat B, Rabaey D, Jansen S. 2011. Testing hypotheses that link wood anatomy to cavitation resistance and hydraulic conductivity in the genus Acer. New Phytologist 190, 709-723.

47. Li S, Lens F, Espino S, Karimi Z, Klepsch M, Schenk HJ, Schmitt M, Schuldt B, Jansen S. 2016. Intervessel pit membrane thickness as a key determinant of embolism resistance in Angiosperm xylem. IAWA Journal 37, 152-171.

48. Lloyd J, Domingues TF, Schrodt F, et al. 2015. Edaphic, structural and physiological contrasts across Amazon Basin forest-savanna ecotones suggest a role for potassium as a key modulator of tropical woody vegetation structure and function. Biogeosciences 12, 6529-6571.

49. Loepfe L, Martinez-Vilalta J, Piñol J, Mencuccini M. 2007. The relevance of xylem network structure for plant hydraulic efficiency and safety. Journal of Theoretical Biology 247, 788-803.

50. Maréchaux I, Bonal D, Bartlett MK, et al. 2018. Dry-season decline in tree sapflux is correlated with leaf turgor loss point in a tropical rainforest. Functional Ecology 32, 2285-2297.

51. Martinelli LA, Almeida S, Brown I, Moreira M, Victoria RL, Sternberg L, Ferreira C, Thomas W. 1998. Stable carbon isotope ratio of tree leaves, boles and fine litter in a tropical forest in Rondonia, Brazil. Oecologia 114, 170-179.

52. Martínez-Vilalta J, Mencuccini M, Álvarez X, Camacho J, Loepfe L, Piñol J. 2012. Spatial distribution and packing of xylem conduits. American Journal of Botany 99, 1189-1196.

53. Mcadam SAM, Brodribb TJ. 2012. Stomatal innovation and the rise of seed plants. Ecology Letters 15, 1-8. 
54. Meinzer FC, Woodruff DR, Domec JC, Goldstein G, Campanello PI, Gatti MG, Villalobos-Vega R. 2008. Coordination of leaf and stem water transport properties in tropical forest trees. Oecologia 156, 31-41.

55. Méndez-Alonzo R, Paz H, Zuluaga RC, Rosell JA, Olson ME. 2012. Coordinated evolution of leaf and stem economics in tropical dry forest trees. Ecology 93, 2397-2406.

56. Niinemets Ü. 2001. Global-scale climatic controls of leaf dry mass per area, density, and thickness in trees and shrubs. Ecology $\mathbf{8 2 , 4 5 3 - 4 6 9 .}$

57. Nijsse J. 2004. On the Mechanism of Xylem Vessel Length Regulation. Plant Physiology 134, 32-34.

58. Nijsse J, Van Der Heijden GWAM, Van leperen W, Keijzer CJ, Van Meeteren U. 2001. Xylem hydraulic conductivity related to conduit dimensions along chrysanthemum stems. Journal of Experimental Botany 52, 319-327.

59. Nobre CA, Borma LDS. 2009. 'Tipping points' for the Amazon forest. Current Opinion in Environmental Sustainability 1, $28-36$.

60. O’Brien MJ, Engelbrecht BMJ, Joswig J, et al. 2017. A synthesis of tree functional traits related to drought-induced mortality in forests across climatic zones. Journal of Applied Ecology 54, 1669-1686.

61. Oliveira RS, Costa FRC, van Baalen E, et al. 2019. Embolism resistance drives the distribution of Amazonian rainforest tree species along hydrotopographic gradients. New Phytologist 221, 1457-1465.

62. Pammenter NW, Willigen C Vander. 1998. A mathematical and statistical analysis of the curves illustrating vulnerability of xylem to cavitation. Tree Physiology 18, 589-593.

63. Pessoa MJG, Santos LM, Abadia AC, Oliveira B, Silva IV, Lenza E. 2021. Floristic composition, diversity and edaphic effects in two rocky savanna communities in the Amazon and Cerrado, Brazil. Ciência Florestal 31, 1383-1406.

64. Pereira L, Bittencourt PRL, Oliveira RS, Junior MBM, Barros F V., Ribeiro R V., Mazzafera P. 2016. Plant pneumatics: Stem air flow is related to embolism - new perspectives on methods in plant hydraulics. New Phytologist 211, 357-370.

65. Pratt RB, Jacobsen AL, Ewers FW, Davis SD. 2007. Relationships among xylem transport, biomechanics and storage in stems and roots of nine Rhamnaceae species of the California chaparral. New Phytologist 174, 787-798.

66. R Development Core Team. R: A Language and Environment for Statistical Computing. Vienna, Austria: R Foundation for Statistical Computing, 2020. https://www.r-project.org/

67. Richardson A, Wojciechowski T, Franke R, Schreiber L, Kerstiens G, Jarvis M, Fricke W. 2007. Cuticular permeance in relation to wax and cutin development along the growing barley (Hordeum vulgare) leaf. Planta 225, 1471-1481.

68. Rosado BHP, Dias ATC, de Mattos EA. 2013. Going back to basics: Importance of ecophysiology when choosing functional traits for studying communities and ecosystems. Natureza a Conservacao 11, 15-22.

69. Rosado BHP, Joly CA, Burgess SSO, Oliveira RS, Aidar MPM. 2016. Changes in plant functional traits and water use in Atlantic rainforest: evidence of conservative water use in spatio-temporal scales. Trees - Structure and Function 30, 47-61.

70. Rosado BHP, De Mattos EA. 2007. Temporal variation of morphological leaf traits in ten species from Restinga of Jurubatiba National Park, Macaé, Rio de Janeiro State, Brazil. Acta Botanica Brasilica 21, 741-752.

71. Rowland L, Da Costa ACL, Galbraith DR, et al. 2015. Death from drought in tropical forests is triggered by hydraulics not carbon starvation. Nature 528, 119-122.

72. Santiago LS, De Guzman ME, Baraloto C, Vogenberg JE, Brodie M, Hérault B, Fortunel C, Bonal D. 2018. Coordination and trade-offs among hydraulic safety, efficiency and drought avoidance traits in Amazonian rainforest canopy tree species. New Phytologist 218, 1015-1024.

73. Scholz A, Klepsch M, Karimi Z, Jansen S. 2013. How to quantify conduits in wood? Frontiers in Plant Science 4, 1-12.

74. Schuster AC, Burghardt M, Riederer M. 2017. The ecophysiology of leaf cuticular transpiration: are cuticular water permeabilities adapted to ecological conditions? Journal of experimental botany $68,5271-5279$.

75. Simioni PF, Eisenlohr PV, Pessoa MJG, Silva IVD. 2017. Elucidating adaptive strategies from leaf anatomy: Do Amazonian savannas present xeromorphic characteristics? Flora: Morphology, Distribution, Functional Ecology of Plants 226.

76. Sperry JS, Donelly JR, Tyree MT. 1988. A method for measuring hydraulic conductivity and embolism in xylem. Plant Cell Environment $11,35-40$.

77. Sperry JS, Hacke UG, Wheeler JK. 2005. Comparative analysis of end wall resistivity in xylem conduits. Plant, Cell and Environment $28,456-465$.

78. Teixeira MC, Trindade FG, Da Cunha M, Rezende CE, Vitória AP. (2018). Alterações ultraestruturais e funcionais do cloroplasto promovendo fotoaclimatação após o manejo florestal em uma floresta tropical secundária. Forest Ecology and Management 428, 27-34.

79. Trueba S, Delzon S, Isnard S, Lens F. 2019. Similar hydraulic efficiency and safety across vesselless angiosperms and vessel-bearing species with scalariform perforation plates. Journal of Experimental Botany 70, 3227-3240.

80. Tyree MT, Zimmermann MH. 2002. Hydraulic Architecture of Whole Plants and Plant Performance. In Xylem structure and the ascent of sap. Springer, Berlin, Heidelberg. pp. 175-214.

81. Vendramini F, Díaz S, Gurvich DE, Wilson PJ, Thompson K, Hodgson JG. 2002. Leaf traits as indicators of resource-use strategy in floras with succulent species. New Phytologist 154, 147-157.

82. Viana PL, Mota NFDO, Gil ADSB, et al. 2016. Flora das cangas da Serra dos Carajás, Pará, Brasil: História, área de estudos e metodologia. Rodriguesia 67, 1107-1124.

83. Vitória AP, Ávila-Lovera E, Oliveira Vieira T, Couto-Santos APL, Pereira TJ, Funch LS, Freitas L, Miranda LAP, Rodrigues PJFP, Rezende CE, Santiago LS. 2018. Isotopic composition of leaf carbon $\left(\delta^{13} \mathrm{C}\right)$ and nitrogen $\left(\delta^{15} \mathrm{~N}\right)$ of deciduous and evergreen understorey trees in two tropical Brazilian Atlantic

Page $11 / 18$ 
forests. Journal of Tropical Ecology, 34, 145-156.

84. Williamson GB, Wiemann MC. 2010. Measuring wood specific gravity...correctly. American Journal of Botany 97, 519-524.

85. Xiong D, Flexas J, Yu T, Peng S, Huang J. 2017. Leaf anatomy mediates coordination of leaf hydraulic conductance and mesophyll conductance to CO2 in Oryza. New Phytologist 213, 572-583.

86. Zanne AE, Westoby M, Falster DS, Ackerly DD, Loarie SR, Arnold SEJ, Coomes DA. 2010. Angiosperm wood structure: Global patterns in vessel anatomy and their relation to wood density and potential conductivity. American Journal of Botany 97, 207-215.

87. Zhang Y, Lamarque LJ, Torres-Ruiz JM, et al. 2018. Testing the plant pneumatic method to estimate xylem embolism resistance in stems of temperate trees. Tree Physiology 38, 1016-1025.

88. Zheng J, Martínez-Cabrera HI. 2013. Wood anatomical correlates with theoretical conductivity and wood density across China: Evolutionary evidence of the functional differentiation of axial and radial parenchyma. Annals of Botany 112, 927-935.

89. Ziemińska K, Butler DW, Gleason SM, Wright IJ, Westoby M. 2013. Fibre wall and lumen fractions drive wood density variation across 24 Australian angiosperms. AoB PLANTS 5, 1-14.

\section{Tables}

Table 1: List of the seven most abundant species in the rocky outcrop Amazonian savanna community, in the town of Nova Canaã do Norte, Mato Grosso, Brazil. PI - Proportion of individuals in relation to the total plot area (764 individuals per ha ${ }^{-1} ; 75 \%$ of the plot species were analyzed).

\begin{tabular}{|c|c|c|c|c|}
\hline \multirow[t]{2}{*}{ Family } & \multirow[t]{2}{*}{ Species } & \multicolumn{3}{|c|}{$\mathrm{PI}$} \\
\hline & & Habit & & Symbol (colour) \\
\hline Calophyllaceae & Kielmeyera rubriflora Cambess. & shrub/tree & $21.35 \%$ & \\
\hline Fabaceae & Parkia cachimboensis H.C.Hopkins & tree & $16.50 \%$ & \\
\hline Melastomataceae & Macairea radula (Bonpl.) DC. & shrub/tree & $12.30 \%$ & \\
\hline Euphorbiaceae & Alchornea discolor Poepp. & shrub/tree & $7.70 \%$ & \\
\hline Marcgraviaceae & Norantea guianensis Aubl. & shrub/tree & $7.70 \%$ & \\
\hline Simaroubaceae & Simarouba versicolor A.St.-Hil & Tree & $5 \%$ & \\
\hline Euphorbiaceae & Maprounea guianensis Aubl. & Tree & $4.45 \%$ & \\
\hline
\end{tabular}

Table 2: Mean of traits measured in each dominant species of the Amazonian savanna (Mean \pm standard deviation). 


\begin{tabular}{|c|c|c|c|c|c|c|c|c|c|}
\hline Traits & Abbreviation & Units & $\begin{array}{l}\text { Kielmeyera } \\
\text { rubriflora }\end{array}$ & $\begin{array}{l}\text { Parkia } \\
\text { cachimboensis }\end{array}$ & $\begin{array}{l}\text { Macairea } \\
\text { radula }\end{array}$ & $\begin{array}{l}\text { Simarouba } \\
\text { versicolor }\end{array}$ & $\begin{array}{l}\text { Maprounea } \\
\text { guianensis }\end{array}$ & $\begin{array}{l}\text { Alchornea } \\
\text { discolor }\end{array}$ & $\begin{array}{l}\text { Norantea } \\
\text { guianensis }\end{array}$ \\
\hline Leaf area & LA & $\mathrm{cm}^{2}$ & $\begin{array}{l}16.99 \pm \\
1.20\end{array}$ & $38.26 \pm 3.17$ & $\begin{array}{l}16.33 \pm \\
0.31\end{array}$ & $\begin{array}{l}17.65 \pm \\
1.31\end{array}$ & $\begin{array}{l}18.21 \pm \\
2.12\end{array}$ & $\begin{array}{l}31.18 \pm \\
4.99\end{array}$ & $\begin{array}{l}58.79 \pm \\
3.81\end{array}$ \\
\hline $\begin{array}{l}\text { Leaf } \\
\text { succulence }\end{array}$ & LS & g.m $m^{-2}$ & $\begin{array}{l}126.45 \pm \\
28.17\end{array}$ & $117.48 \pm 22.25$ & $\begin{array}{l}279.31 \pm \\
14.58\end{array}$ & $\begin{array}{l}177.64 \pm \\
8.84\end{array}$ & $\begin{array}{l}78.56 \pm \\
10.89\end{array}$ & $\begin{array}{l}54.96 \pm \\
4.08\end{array}$ & $\begin{array}{l}151.66 \pm \\
6.83\end{array}$ \\
\hline $\begin{array}{l}\text { Leaf mass } \\
\text { per area }\end{array}$ & LMA & g.m $m^{-2}$ & $\begin{array}{l}59.21 \pm \\
13.17\end{array}$ & $67.00 \pm 14.05$ & $\begin{array}{l}102.85 \pm \\
17.71\end{array}$ & $\begin{array}{l}116.07 \pm \\
22.17\end{array}$ & $\begin{array}{l}59.45 \pm \\
9.37\end{array}$ & $\begin{array}{l}78.79 \pm \\
8.85\end{array}$ & $\begin{array}{l}120.31 \pm \\
11.70\end{array}$ \\
\hline $\begin{array}{l}\text { Stomatal } \\
\text { density }\end{array}$ & SD & $\mathrm{mm}^{2}$ & $\begin{array}{l}27.59 \pm \\
0.68\end{array}$ & $25.36 \pm 2.89$ & $\begin{array}{l}34.93 \pm \\
4.62\end{array}$ & $\begin{array}{l}25.40 \pm \\
0.40\end{array}$ & $\begin{array}{l}28.47 \pm \\
2.04\end{array}$ & $\begin{array}{l}10.40 \pm \\
0.72\end{array}$ & $\begin{array}{l}10.27 \pm \\
0.64\end{array}$ \\
\hline $\begin{array}{l}\text { Adaxial } \\
\text { cuticle }\end{array}$ & $A C$ & $\mu \mathrm{m}$ & $\begin{array}{l}1.81 \pm \\
0.27\end{array}$ & $2.84 \pm 0.67$ & $\begin{array}{l}8.13 \pm \\
3.38\end{array}$ & $\begin{array}{l}3.10 \pm \\
0.12\end{array}$ & $7.07 \pm 2.11$ & $\begin{array}{l}8.22 \pm \\
1.38\end{array}$ & $\begin{array}{l}4.93 \pm \\
0.22\end{array}$ \\
\hline $\mathrm{G}_{\max }$ & $\mathrm{G}_{\max }$ & $\mathrm{mm} \cdot \mathrm{s}^{-1}$ & $\begin{array}{l}165.03 \pm \\
11.83\end{array}$ & $197.73 \pm 3.90$ & $\begin{array}{l}276.56 \pm \\
34.61\end{array}$ & $\begin{array}{l}241.85 \pm \\
16.34\end{array}$ & $\begin{array}{l}173.47 \pm \\
5.70\end{array}$ & $\begin{array}{l}101.12 \pm \\
4.74\end{array}$ & $\begin{array}{l}114.87 \pm \\
4.49\end{array}$ \\
\hline WUE $\left(\delta^{13} \mathrm{C}\right)$ & WUE & $\%$ & $\begin{array}{l}-28.80 \pm \\
0.10\end{array}$ & $-30.07 \pm 0.65$ & $\begin{array}{l}-29.5 \pm \\
0.17\end{array}$ & $\begin{array}{l}-30.77 \pm \\
0.71\end{array}$ & $\begin{array}{l}-28.43 \pm \\
0.21\end{array}$ & $\begin{array}{l}-28.53 \pm \\
0.21\end{array}$ & $\begin{array}{l}-27.20 \pm \\
0.10\end{array}$ \\
\hline $\mathrm{K}_{\mathrm{th}}$ & $\mathrm{K}_{\mathrm{th}}$ & $\mathrm{kg} \cdot \mathrm{s}^{-1} \cdot \mathrm{m}^{-1} \cdot \mathrm{MPa}^{-1}$ & $\begin{array}{l}2.54 \mathrm{E}+09 \\
\pm \\
6.16 \mathrm{E}+08\end{array}$ & $\begin{array}{l}3.90 \mathrm{E}+09 \pm \\
1.60 \mathrm{E}+09\end{array}$ & $\begin{array}{l}6.48 \mathrm{E}+08 \\
\pm \\
5.30 \mathrm{E}+07\end{array}$ & $\begin{array}{l}4.53 \mathrm{E}+09 \\
\pm \\
1.38 \mathrm{E}+09\end{array}$ & $\begin{array}{l}1.67 E+09 \pm \\
8.00 E+08\end{array}$ & $\begin{array}{l}7.10 \mathrm{E}+09 \\
\pm \\
2.89 \mathrm{E}+09\end{array}$ & $\begin{array}{l}4.28 \mathrm{E}+09 \\
\pm \\
1.89 \mathrm{E}+09\end{array}$ \\
\hline $\begin{array}{l}\text { Vessel } \\
\text { lumen area }\end{array}$ & VLA & $\mu \mathrm{m}$ & $\begin{array}{l}3489.52 \pm \\
443.91\end{array}$ & $\begin{array}{l}3455.80 \pm \\
490.09\end{array}$ & $\begin{array}{l}2450.62 \\
\pm 472.66\end{array}$ & $\begin{array}{l}3716.75 \pm \\
781.53\end{array}$ & $\begin{array}{l}2398.84 \pm \\
275.69\end{array}$ & $\begin{array}{l}6636.97 \pm \\
1139.66\end{array}$ & $\begin{array}{l}4914.62 \pm \\
293.20\end{array}$ \\
\hline $\begin{array}{l}\text { Frequency } \\
\text { vessel }\end{array}$ & $\mathrm{FV}$ & $\mathrm{mm}^{2}$ & $\begin{array}{l}44.31 \pm \\
16.79\end{array}$ & $57.83 \pm 6.67$ & $\begin{array}{l}93.47 \pm \\
12.78\end{array}$ & $\begin{array}{l}74.68 \pm \\
18.00\end{array}$ & $\begin{array}{l}49.79 \pm \\
9.53\end{array}$ & $\begin{array}{l}30.12 \pm \\
10.32\end{array}$ & $\begin{array}{l}39.93 \pm \\
12.09\end{array}$ \\
\hline $\begin{array}{l}\text { Vessel } \\
\text { element } \\
\text { length }\end{array}$ & VL & $\mu \mathrm{m}$ & $\begin{array}{l}418.48 \pm \\
38.54\end{array}$ & $205.28 \pm 4.17$ & $\begin{array}{l}360.13 \pm \\
35.27\end{array}$ & $\begin{array}{l}311.55 \pm \\
16.80\end{array}$ & $\begin{array}{l}461.53 \pm \\
52.60\end{array}$ & $\begin{array}{l}658.23 \pm \\
106.32\end{array}$ & $\begin{array}{l}714.85 \pm \\
78.65\end{array}$ \\
\hline $\begin{array}{l}\text { Lumen } \\
\text { fraction }\end{array}$ & LF & & $\begin{array}{l}0.24 \pm \\
0.02\end{array}$ & $0.35 \pm 0.07$ & $\begin{array}{l}0.30 \pm \\
0.03\end{array}$ & $\begin{array}{l}0.37 \pm \\
0.04\end{array}$ & $0.27 \pm 0.01$ & $\begin{array}{l}0.18 \pm \\
0.02\end{array}$ & $\begin{array}{l}0.21 \pm \\
0.03\end{array}$ \\
\hline $\begin{array}{l}\text { Ray } \\
\text { frequency }\end{array}$ & RF & mm' & $\begin{array}{l}8.70 \pm \\
0.79\end{array}$ & $10.14 \pm 0.57$ & $\begin{array}{l}10.26 \pm \\
1.41\end{array}$ & $\begin{array}{l}7.93 \pm \\
1.02\end{array}$ & $\begin{array}{l}14.09 \pm \\
0.43\end{array}$ & $\begin{array}{l}11.05 \pm \\
0.36\end{array}$ & $\begin{array}{l}4.79 \pm \\
1.19\end{array}$ \\
\hline Ray width & RW & $\mu \mathrm{m}$ & $\begin{array}{l}19.78 \pm \\
0.80\end{array}$ & $14.79 \pm 3.32$ & $\begin{array}{l}12.18 \pm \\
2.50\end{array}$ & $\begin{array}{l}35.64 \pm \\
1.80\end{array}$ & $\begin{array}{l}14.95 \pm \\
2.82\end{array}$ & $\begin{array}{l}22.91 \pm \\
1.10\end{array}$ & $\begin{array}{l}84.24 \pm \\
9.09\end{array}$ \\
\hline $\begin{array}{l}\text { Fiber } \\
\text { length }\end{array}$ & $\mathrm{FL}$ & $\mu \mathrm{m}$ & $\begin{array}{l}654.45 \pm \\
60.22\end{array}$ & $647.53 \pm 51.42$ & $\begin{array}{l}456.38 \pm \\
20.26\end{array}$ & $\begin{array}{l}540.74 \pm \\
15.71\end{array}$ & $\begin{array}{l}723.51 \pm \\
58.11\end{array}$ & $\begin{array}{l}1095.58 \pm \\
108.46\end{array}$ & $\begin{array}{l}1005.62 \pm \\
86.88\end{array}$ \\
\hline $\begin{array}{l}\text { Fiber } \\
\text { lumen }\end{array}$ & $\mathrm{FL}$ & $\mu \mathrm{m}$ & $\begin{array}{l}7.72 \pm \\
0.64\end{array}$ & $7.17 \pm 1.19$ & $\begin{array}{l}7.21 \pm \\
1.18\end{array}$ & $\begin{array}{l}7.77 \pm \\
0.51\end{array}$ & $8.31 \pm 0.34$ & $\begin{array}{l}14.92 \pm \\
1.17\end{array}$ & $\begin{array}{l}16.67 \pm \\
0.81\end{array}$ \\
\hline $\begin{array}{l}\text { Wood } \\
\text { specific } \\
\text { gravity }\end{array}$ & WSG & g. $\mathrm{cm}^{-3}$ & $\begin{array}{l}0.57 \pm \\
0.03\end{array}$ & $0.49 \pm 0.04$ & $\begin{array}{l}0.63 \pm \\
0.01\end{array}$ & $\begin{array}{l}0.51 \pm \\
0.04\end{array}$ & $0.48 \pm 0.01$ & $\begin{array}{l}0.50 \pm \\
0.04\end{array}$ & $\begin{array}{l}0.46 \pm \\
0.02\end{array}$ \\
\hline $\begin{array}{l}\text { Vessel wall } \\
\text { thickness }\end{array}$ & VWT & $\mu \mathrm{m}$ & $\begin{array}{l}2.84 \pm \\
0.26\end{array}$ & $3.46 \pm 0.55$ & $\begin{array}{l}2.52 \pm \\
0.39\end{array}$ & $\begin{array}{l}2.56 \pm \\
0.18\end{array}$ & $3.81 \pm 0.23$ & $\begin{array}{l}5.23 \pm \\
0.66\end{array}$ & $\begin{array}{l}3.95 \pm \\
0.25\end{array}$ \\
\hline $\begin{array}{l}\text { Intervessel } \\
\text { pits }\end{array}$ & IPit & $\mu \mathrm{m}$ & $\begin{array}{l}8.77 \pm \\
1.20\end{array}$ & $6.48 \pm 0.79$ & $\begin{array}{l}5.66 \pm \\
0.16\end{array}$ & $\begin{array}{l}5.57 \pm \\
0.17\end{array}$ & $4.41 \pm 0.34$ & $\begin{array}{l}11.36 \pm \\
0.65\end{array}$ & $\begin{array}{l}8.47 \pm \\
0.29\end{array}$ \\
\hline $\begin{array}{l}\text { Thickness } \\
\text { pit } \\
\text { membrane }\end{array}$ & $\mathrm{T}_{\mathrm{pm}}$ & $\mu \mathrm{m}$ & $\begin{array}{l}0.31 \pm \\
0.04\end{array}$ & $0.39 \pm 0.04$ & $\begin{array}{l}0.33 \pm \\
0.02\end{array}$ & $\begin{array}{l}0.32 \pm \\
0.02\end{array}$ & $0.41 \pm 0.04$ & $\begin{array}{l}0.33 \pm \\
0.01\end{array}$ & $\begin{array}{l}0.27 \pm \\
0.006\end{array}$ \\
\hline$P_{50}$ & $P_{50}$ & $\mathrm{MPa}$ & $\begin{array}{l}-3.87 \pm \\
0.08\end{array}$ & $-5.07 \pm 0.46$ & NA & $\begin{array}{l}-4,40 \pm \\
0,32\end{array}$ & $-4,56 \pm 0,92$ & NA & $\begin{array}{l}-1.66 \pm \\
0.06\end{array}$ \\
\hline HSM & HSM & $\mathrm{MPa}$ & $\begin{array}{l}2.84 \pm \\
0.03\end{array}$ & $3.85 \pm 0.19$ & NA & $\begin{array}{l}2,62 \pm \\
0,19\end{array}$ & $3,37 \pm 0,97$ & NA & $\begin{array}{l}0.48 \pm \\
0.12\end{array}$ \\
\hline
\end{tabular}




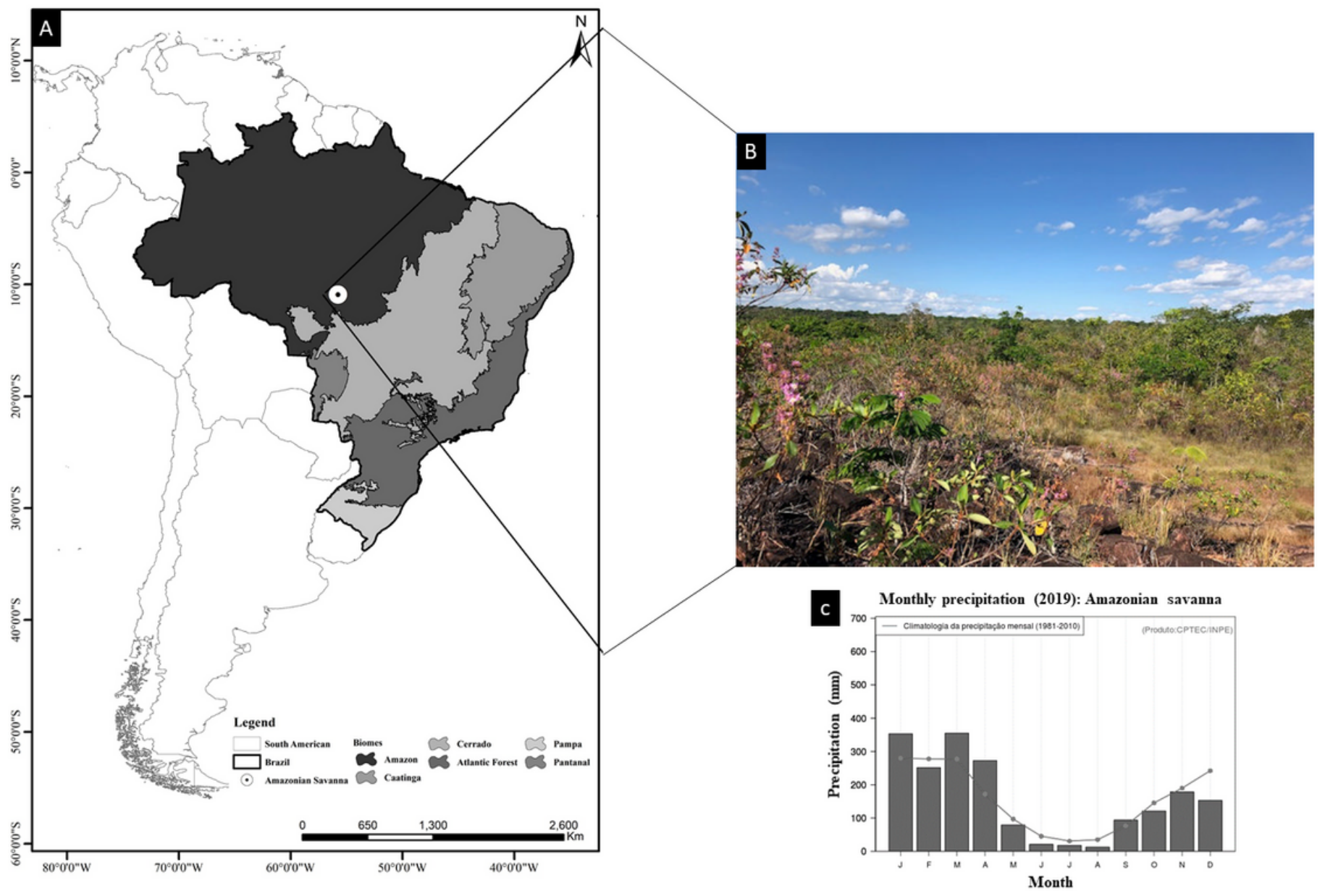

Figure 1

Study region, in North Brazil: (A) Map of the study region, in North Brazil, showing the specific location; (B) Amazonian savanna landscape with vegetation occur in rocky outcrop seasonally-dry environments; (C) Climate graph with average rainfall for 2019 (Fonte: INPE). 


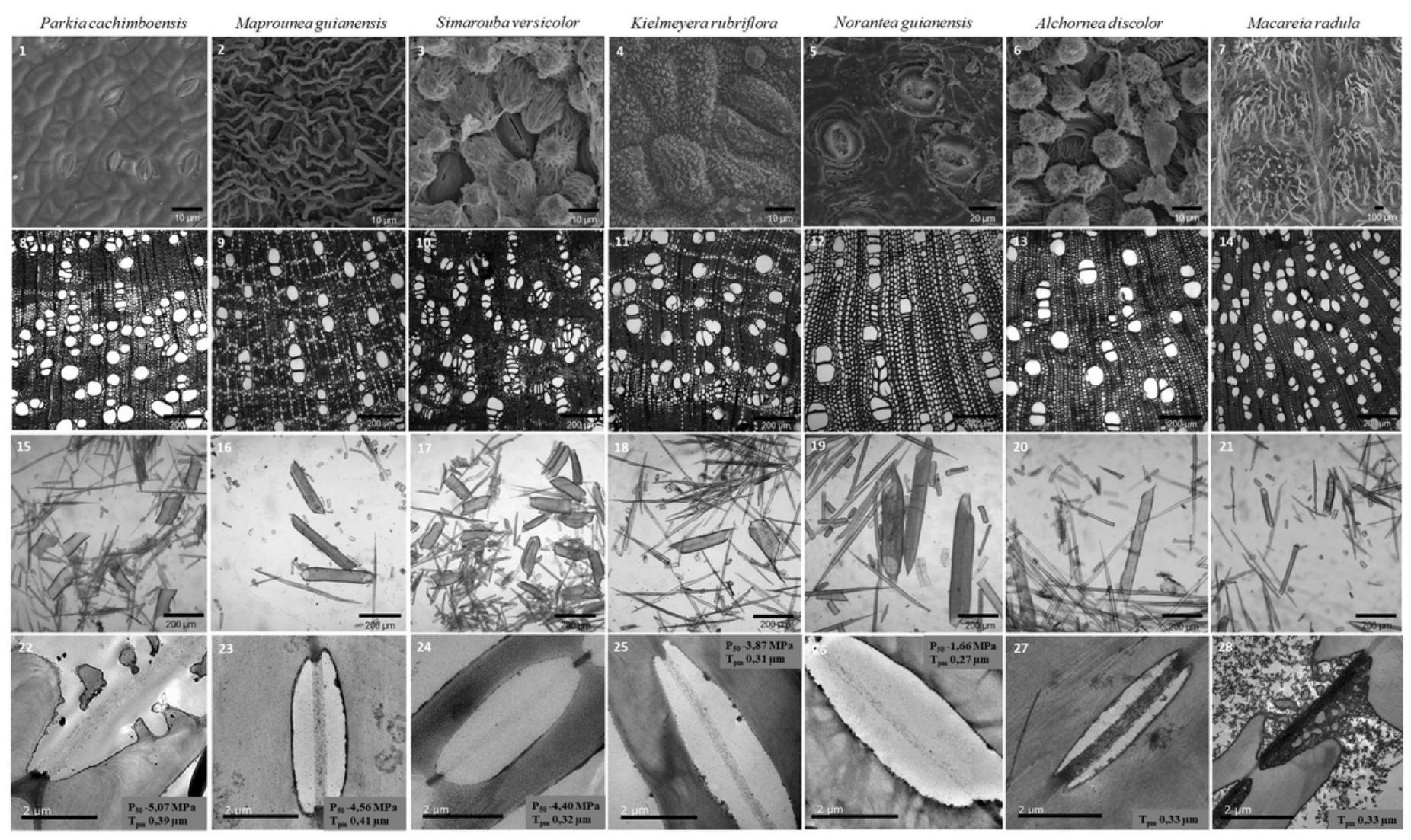

Figure 2

Leaf and wood anatomy of each dominant species in the studied Amazonian savanna. Images 1 to 7 : scanning electron microscopy showing different sizes of stomatal pores and layers of epicuticular wax. Images 8 to 14: light microscopy showing the different frequencies of vessels, lumen area, lumen fractions by area. Images 15 to 21 : light microscopy showing the different length of vessel elements. Image 22 to 28 : transmission electron microscopy showing pit membrane thickness. 
A
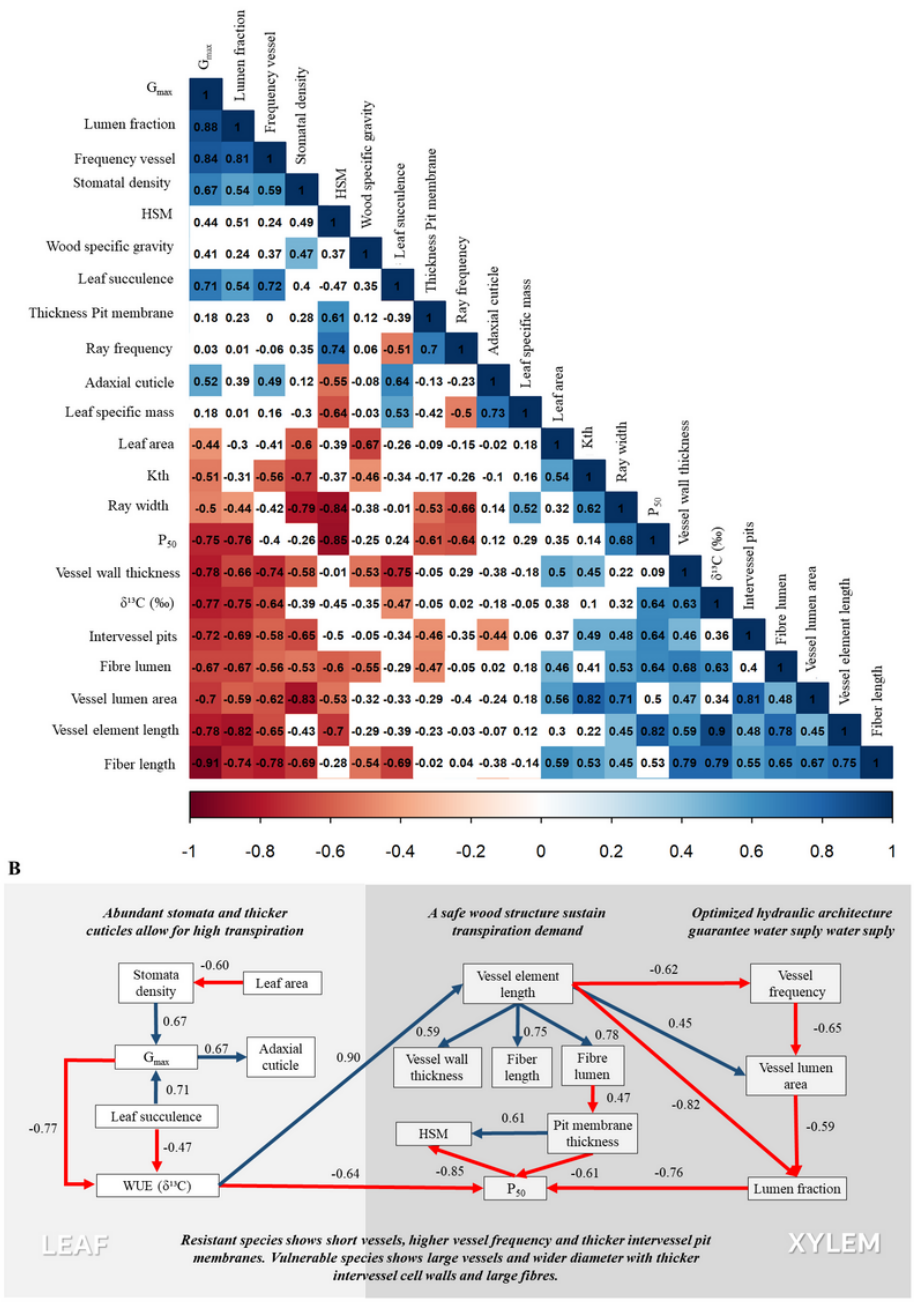

Figure 3

(A) Matrix of Spearman's correlation coefficients between anatomical and hydraulic leaf and wood traits. Red represents negative correlations and blue represents positive correlations (significance level is $p<0.05$ ). (B) Diagram illustrating how the observed correlations could be interpreted in terms of following this study hypothesis. Stomata density decreases with leaf area with impacts to WUE through Gmax. Here, high Gmax is sustained by thick adaxial cuticles and high degree of leaf succulence. As WUE decreases, P50 increases. This functional relationship is sustained by a series of structural relationships where vessel element length is a central feature. Vessel wall thickness, vessel lumen area, fiber length and fiber lumen increase with vessel element length while pit membrane thickness, vessel frequency and lumen fraction decreases, both with negative impacts to P50 and HSM. Please note that directions of arrows are suggestive of our interpretation as results here are based in correlations that may not imply causation. Red arrows represent negative correlations and black arrows represent positive correlations. Significance level for correlation coefficients $(r)$ is $p<0.05$ Spearman's. 

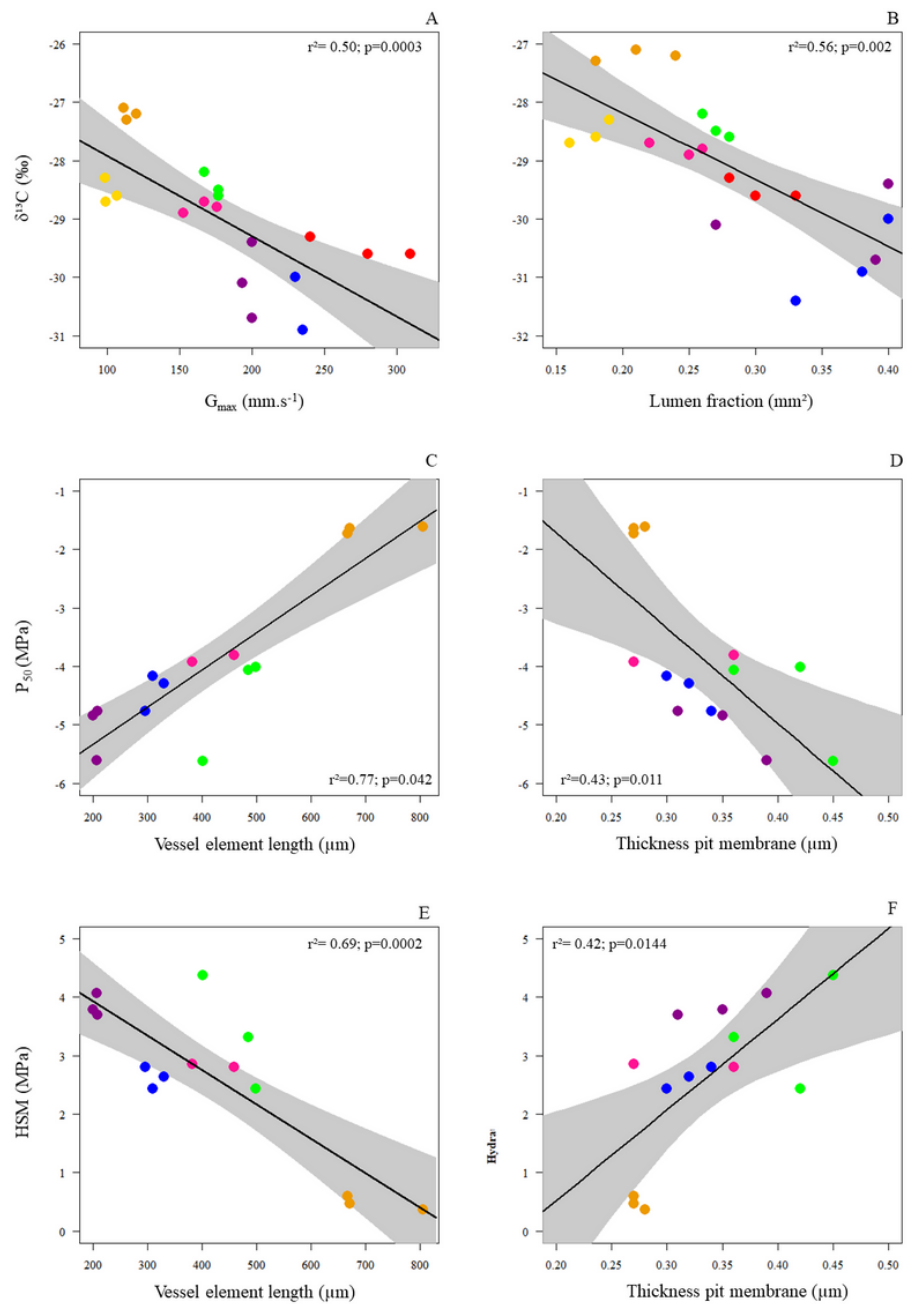

\section{Figure 4}

Relationships among anatomical and hydraulic traits of the seven dominant species in the studied community (A); relationships among $\delta^{13} \mathrm{C}$ and $\mathrm{Gmax}$ (B) and lumen fraction; (C) relationship among $\mathrm{P}_{50}$ and vessel-element length (D) and pit membrane thickness; (E) relationship among HSM (Hydraulic safety margin) and element vessel length (F) and pit membrane thickness (F) solid lines represent a significant linear relationship. (Significance level $p$ $<0.05$ ). Regressions were corrected by Bonferroni coefficient (see Table S1). 


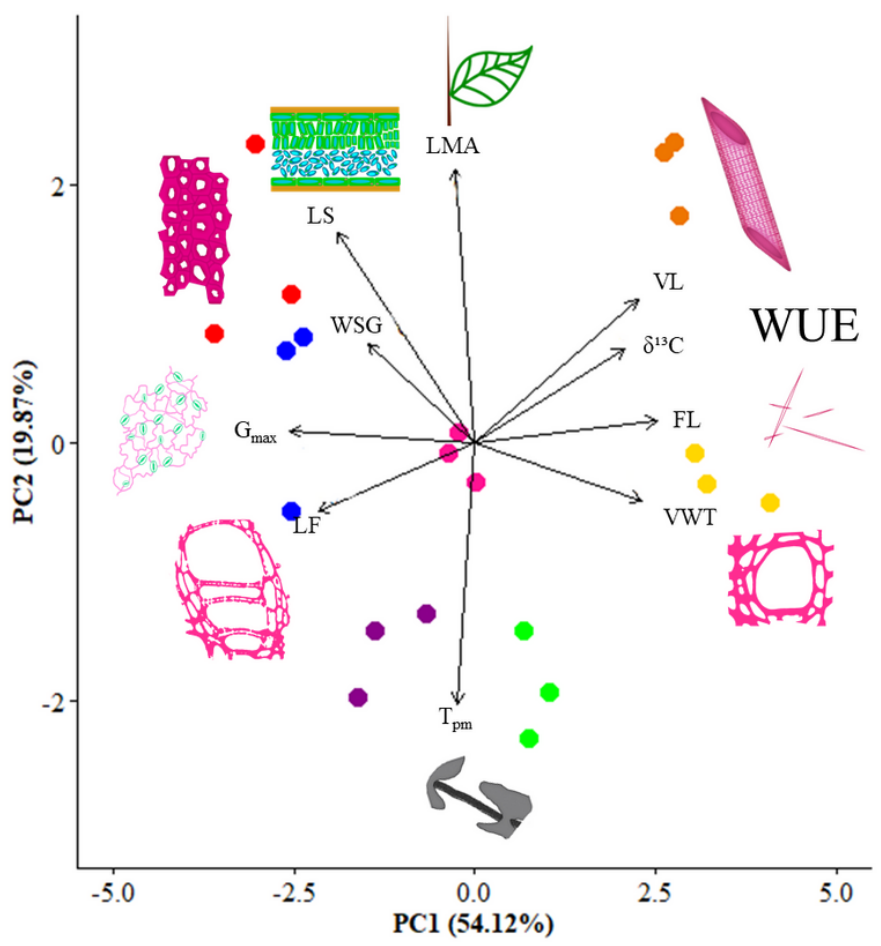

Figure 5: Principal component analysis (PCA) of the dominant species of the studied Amazonian savanna. LMA - leaf mass per área; LS - leaf succulence; WSG - wood specific gravity; $\mathrm{G}_{\max }$ - maximum stomatal conductance; LF - lumen fraction; VWT - vessel wall thickness; Tpm - pit membrane thickness; $\delta^{13} \mathrm{C}$ - carbon isotope; VL - vessel-element length and FL - fiber length. Alchornea discolor ; Kielmeyera rubriflora ; Macareia radula Maprounea guianensis ; Norantea guianensis $\bigcirc$;imarouba versicolor $\bigcirc$ Parkia cachimboensis .

\section{Figure 5}

See image above for figure legend.

\section{Supplementary Files}

This is a list of supplementary files associated with this preprint. Click to download.

- Simioniet2021SupplementalFiles.doc 